\title{
The influence of Indian languages on the functioning of grammatical forms in Spanish in the Mexican state of Oaxaca
}

\author{
Irina Smirnova ${ }^{1, *}$, Victoria Vetrinskaya $^{1}$, and Svetlana Clemente-Smirnova ${ }^{1}$ \\ ${ }^{1}$ RUDN University, 6, Miklukho-Maklaya str. 117198, Moscow, Russia
}

\begin{abstract}
The article deals with the local-specific features of the functioning of grammatical forms in the Spanish language of the Mexican state of Oaxaca. Examples of the influence of Native American languages on the grammatical structure of the Spanish language are analyzed and given. The co-existence of the dominant Spanish and Indian languages had an impact on the Mexican variant of Spanish. During the three hundred years of Spanish colonization, the cultural diversity of the State of Oaxaca was mixed and expanded. Thus, a mixture of Spanish, autochthonous and African groups emerged, which defined the language of the residents of the region in particular. The implementation of language units in the state is characterized by a peculiarity that is expressed at the grammatical level. The purpose of the article is to analyze the influence of Indian languages on the grammatical structure of Spanish in the Mexican state of Oaxaca. The research was based on articles, fiction written by Oaxaca authors. Textbooks on grammar of autochthonous languages of the Oto-Manguean group were studied. Interviews with governors, poets, state linguists and Oaxacan speakers in markets, streets, cafes were analyzed. As a result of the study, the Oaxaca resident's speech revealed grammatical features influenced by Indian languages that distinguish local speech from that of the capital. As a result of the findings, there are prospects for further research into the influence of indigenous languages on Spanish in the State of Oaxaca.
\end{abstract}

\section{Introduction}

Spanish is one of the most widely spoken languages in the world. Despite the linguistic commonality of the Hispanic peoples, the Spanish language is characterized by a wide territorial variability. The Spanish language is characterized by its own national characteristics in each individual country.

Mexico is the largest Spanish-speaking country. According to a study by the National Institute of Statistics and Geography (Instituto Nacional de Estadística y Geografía (Inegi)) conducted in Mexico in 2020 and published in January 2021, Mexico has a total population of $126,014,024$. [7]

\footnotetext{
*Corresponding author: nomeolvides333@yandex.ru
} 
The Spanish in Mexico is one of the unique language formations in terms of «the diversity of forms of its existence or state as a set of types of variability». [4]

After the conquest of Mexico by the Spanish colonizers, the large cities were inhabited mainly by wealthy educated elite. As a result, the literary version of the Castilian language was remained largely intact. Far from the cities and educational centers, the Spanish language was undergoing changes not only by itself, but also under the influence of the Indian American language. [1] "As the indigenous people studied the various dialects of the colonizers, new 'variants' of Spanish developed". [2] Following Moreno de Alba, O. S. Chesnokova emphasizes that "the linguistic contacts of the Spanish language and the autochthonous languages of Mexico have found both cultural-anthropological and infrastructural linguistic embodiment. The modern Spanish in Mexico is an eloquent reflection of the dynamics of the processes of spatial and temporal differentiation and integration of the Spanish language". [5]

The heterogeneity and variability of Spanish within Mexico determines its dialect diversity, i.e. the Mexican national variant exists in the form of intra-national dialects. The dialect differences of Spanish of Mexico have been repeatedly studied since the end of the 19 th century.

The state of Oaxaca is one of the 31 states of Mexico, located in the southwest of the country. Spanish in the state has distinctive features. According to the classification of $\mathrm{P}$. Henríquez Ureña (1921), where the scientist identifies 6 dialectal zones in Mexico, which are characterized by phonological and lexical features, the state of Oaxaca is included in the southern zone. [12] Taking into account the later classification of J. M. Lope Blanch, the state of Oaxaca is included in the coastal zone along with the state of Guerrero, and also forms a separate Oaxaca Highlands zone. [13] The sociolinguistic status of Spanish in the Mexican state of Oaxaca is usually defined as a territorial dialect within the Mexican national variant of the Spanish language.

This State offers a great opportunity to study it from a linguistic point of view, as it is the most ethnically and linguistically diverse State in the country. Sixteen out of the 65 existing ethnic groups in Mexico live in the State of Oaxaca. In Oaxaca, 32 out of every 100 residents aged 3 or older speak an indigenous language. Six out of ten residents of the state identify themselves as Indians, belong to one of the ethnic groups and speak Indian languages. [10]

Studying the features of the functioning of grammatical forms in the Spanish language of the Mexican state of Oaxaca, it was revealed that there were grammatical features in the speech of the inhabitants of Oaxaca that distinguish the local speech from the Mexican norm, and are used by most residents of the state regardless of their social level and education, i.e. is not a colloquial language. This study led to a hypothesis about the influence of the languages of the Oto-Manguean group on the grammatical structure of Spanish in this region.

\section{Methods}

The research was based on articles, essays, and literary works written by Oaxaca authors. As well as folklore, legends, and stories translated from Indian American languages into Spanish. The grammar textbooks of the Oto-Manguean group (Zapotec, Mazatec, Mixtec, Mixe, and Amuzgo languages) were also reviewed and analyzed to confirm the possible influence of local Indian languages on the grammatical structure of Spanish in the state. Interviews of governors, poets, and linguists of the state from Internet sources were analyzed. The speech of Oaxaca residents in markets, streets, cafes, recorded on a recorder, and collected by testing, questionnaires and interviews of information of different age and social groups ( 80 persons) were studied. 
Indian speakers were selected by age group and social affiliation. Children (5-14 years old), young people (17-30 years old), middle-aged people (30-50 years old) and elderly people (50-85 years old) were interviewed. The survey of informants was conducted directly in the state of Oaxaca in 2016, 2017, 2018 and remotely in 2020.

The method of direct observation and analytical description of linguistic facts, functional, comparative, statistical methods, interviewing of informants, and the use of the global Internet were used in the work.

\section{Results}

Analyzing the use of nouns in the state of Oaxaca, it was found that such a grammatical category as a number does not correspond to the generally accepted Spanish norm. At first glance, it may seem that Oaxacans prefer generic concepts and use nouns in singular terms when other Mexican speakers usually use plural. For example:

- Yo empecé a tejer $\boldsymbol{e l}$ sombrero a la edad de 7 años "I started making hats at 7 years old". (Record)

- Se dedican principalmente a la pesca de camarón en las lagunas marinas del golfo de Tehuantepec, los hombres $\boldsymbol{l o}$ pescan y las mujeres $\boldsymbol{l o}$ venden. "They are mainly engaged in shrimp fishing in the sea lagoons of the Gulf of Tehuantepec. Men catch them, and women sell them". (Record)

There is also the phenomenon of the use of the word in a number corresponding to the Mexican norm and the determining parts of speech having a different number, which confirms the fact that, by using the word in a singular number, Oaxacans mean plural. For example:

- Aunque los habitantes de pueblos cercanos generalmente se entienden entre sí, la gente de cada pueblo habla un poco distinto a la gente de los pueblos vecinos, ya sea porque tengan una pronunciación o vocabulario diferente... "Although residents of nearby cities usually understand each other, residents of each city speak slightly differently than residents of neighboring cities, either because they have a different pronunciation or vocabulary..." [9]

- Les expliqué ampliamente al señores "I explained in detail to men". (Record)

It can be said that for residents of the state the category of number is not important, but analyzing the grammars of Indian languages, it was revealed that there is no number, i.e. nouns do not decline for number, i.e. the same form denotes both singular and plural. Most likely, due to the lack of a number category, Oaxacans often use Spanish words in the singular, thus giving the impression that a generic concept is used. For example, in Mixtec, "ve'e" is both casa "house" and casas "houses":

- iin $\boldsymbol{v} \boldsymbol{e} \boldsymbol{e} \rightarrow$ una casa $\rightarrow$ "one house"

- uu v $\boldsymbol{e}^{\prime} \boldsymbol{e} \rightarrow$ dos casas $\rightarrow$ "two houses" [6]

In this case, the plural is indicated by cardinal numerals. For example, in the Amuzgo language, the prefix $\mathbf{- n}$ serves as a number designation for a number of nouns:

- che $\rightarrow$ "bolso" $\rightarrow$ bag; $\boldsymbol{n c h e ~} \rightarrow$ "bolsos" $\rightarrow$ bags

- chi'tan $\rightarrow$ "abuela" $\rightarrow$ grandmother; $\boldsymbol{n}$ chi'tan $\rightarrow$ "abuelas" $\rightarrow$ grandmothers

In some areas, when forming the plural in Spanish, -s is omitted, and the final vowel is lengthened. The letter does not reflect this in any way:

- Estamos agradecido por todo "We are grateful for everything". (Record)

This phenomenon occurs in the Mazatec language. Here, changing the tone, raising it, changes the number:

- natsiee - conejo - "rabbit"; natsié - conejos - "rabbits"

- naña - perro - "dog"; nañá - perros - "dogs". [14] 
It can be suggested that the phonetic elongation of the final vowel and the absence of the final $-\mathbf{s}$ is the result of the superimposition of Indian grammar on Spanish.

There is a high frequency of use of adjectives in the position before the noun (adj.+noun.):

- Pasados los días, las personas que caminaban junto a su casa, veían a un extraño animal, que se posaba sobre una roca. "Every day, people passing by his house saw a strange animal sitting on a rock". [6]

- Con ellas he pasado incontables horas discutiendo y desentranando el significado de muchas de las palabras que aparecen en estas narraciones. "I spent many hours with them, discussing and deciphering the meaning of many words that appear in these stories". [17]

The influence of Indian languages is also traced, as some languages of the OtoManguean group, have adjectives placed before the noun and do not change in gender and number, as can be seen from the literal translation:

Table 1. Comparative analysis of phrases.

\begin{tabular}{|c|c|c|c|c|}
\hline Language & $\begin{array}{l}\text { Indian } \\
\text { phrase }\end{array}$ & $\begin{array}{l}\text { Word-for-word } \\
\text { translation into } \\
\text { Spanish }\end{array}$ & $\begin{array}{l}\text { Loose translation } \\
\text { into Spanish }\end{array}$ & $\begin{array}{c}\text { English } \\
\text { translation }\end{array}$ \\
\hline Mazatec & $\begin{array}{l}\text { Xi cavuya } \\
\text { me ne, } \\
\text { tyjahi tsjian } \\
\text { rë me. } \\
\text { Hacuaha } \\
\text { jercu } \\
\text { ndajyihi. }\end{array}$ & $\begin{array}{l}\text { Al regresar él, } \\
\text { limpio ropa de él. } \\
\text { También muy } \\
\text { bonito }\end{array}$ & $\begin{array}{l}\text { Cuando Dios regresó, } \\
\text { su ropa estaba limpia. } \\
\text { Y estaba muy bonita. }\end{array}$ & $\begin{array}{l}\text { When } \\
\text { returned, God } \\
\text { clothes were clean } \\
\text { and very beautiful }\end{array}$ \\
\hline Amuzgo & $\begin{array}{l}\text { Ncyaa' } \\
\text { Juanhan }\end{array}$ & Miedoso Juan & Juan es miedoso & Juan is a coward. \\
\hline Mixe & $\begin{array}{l}\text { Xütz oоy yi } \\
\text { tü' aa. }\end{array}$ & $\begin{array}{l}\text { Angosto muy el } \\
\text { camino. }\end{array}$ & $\begin{array}{l}\text { Está muy angosto el } \\
\text { camino. }\end{array}$ & Very narrow road. \\
\hline
\end{tabular}

A distinctive feature of Oaxacan speech is the use of a personal pronoun with a verb. Oaxacans practically do not use sentences without a subject. Personal pronouns can be used both before and after the verb.

- No, tío, por favor no me comas, no estoy sabroso, porque soy muy pequeño. Si tú quieres, vamos a comer estas tunas porque están muy dulces. "No, buddy, please don't eat me, I don't taste nice because I'm too small. If you want, we can eat these tunas, because they are very sweet". [6]

- Mira, como lo hago yo. "Watch me do it". (Record)

It can be suggested that this is due to the influence of Indian languages, where the verb requires the use of a personal pronoun. Among the Mazatecs, Zapotecs, and Mixtecs, the sentence is constructed as follows: verb+p.pr.:

Table 2. Comparative analysis of phrases.

\begin{tabular}{|l|l|l|l|l|}
\hline Language & \multicolumn{1}{|c|}{$\begin{array}{c}\text { Indian } \\
\text { phrase }\end{array}$} & $\begin{array}{l}\text { Word-for-word } \\
\text { translation into } \\
\text { Spanish }\end{array}$ & $\begin{array}{l}\text { Loose translation } \\
\text { into Spanish }\end{array}$ & \multicolumn{1}{c|}{$\begin{array}{c}\text { English } \\
\text { translation }\end{array}$} \\
\hline Mazatec & $\begin{array}{l}\text { Cachja cha xi } \\
\text { cuinduva me. }\end{array}$ & $\begin{array}{l}\text { Habló él que } \\
\text { vendrán ellos }\end{array}$ & El dijo que vendrán & $\begin{array}{l}\text { He sai they } \\
\text { would come }\end{array}$ \\
\hline Mixtec & $\begin{array}{l}\text { lin kuu ni } \\
\text { sa'an ndu ni } \\
\text { sadikí ndu } \\
\text { sakuaa. }\end{array}$ & $\begin{array}{l}\text { Un día fuimos } \\
\text { nosotros cazamos } \\
\text { nosotros venado }\end{array}$ & $\begin{array}{l}\text { Un día fuimos a cazar } \\
\text { venado. }\end{array}$ & $\begin{array}{l}\text { One day we went } \\
\text { deer hunting. }\end{array}$ \\
\hline Zapotec & $\begin{array}{l}\text { Uyojë' yedyi } \\
\text { re' ga'la'. }\end{array}$ & $\begin{array}{l}\text { Fue }- \text { ellos pueblo } \\
\text { está.sentado cerca }\end{array}$ & $\begin{array}{l}\text { Ellos fueron a un } \\
\text { pueblo que está cerca. }\end{array}$ & $\begin{array}{l}\text { They went to a } \\
\text { town nearby. }\end{array}$ \\
\hline
\end{tabular}


Oaxacans use the form of the dative case not only in relation to the person, but also to the object. Here a hypothesis can be put forward is related to the Indian world view, which gives life to inanimate objects, in the European sense, or it may be due to the lack of gender in Indian languages. For example:

- El hoyo se le tapa con palmas. "The pit is laid with palm leaves". (Record)

- No se le pide nada a Italia. "We don't order anything in Italy". (Record)

- El huave es una lengua aislada, se desconoce su origen, aunque se le ha intentado atribuir, sin éxito, orígenes sudamericanos. "El Huave is an isolated language, its origin is unknown, although it has been unsuccessfully tried to attribute a South American origin". [11]

Both in written and oral speech, the pronoun can be used simultaneously in both the dative and accusative cases in different genders and numbers relative to the same object:

- La cueva lo ocupamos para tejer el sombrero. "We use the cave to make hats". (Record)

- Cuando se los daban a los pollos, no recogían el maíz sobrante, nadie le daba ningún valor al maiz. "When they gave it to the chickens, they didn't pick the remaining corn, no one gave the corn any importance". [17]

Instead of the article, Oaxacans most often use possessive pronouns. It should be noted that possessive pronouns, as well as non-possessive pronouns, refer not only to a person, but also to an object. For example: a river, an animal, a house, a device. There is also an element of the Indian consciousness that everything has life: rocks, mountains, rivers, etc.:

- Si quieren recrearse vienen para ver el río. El río, $\boldsymbol{s} \boldsymbol{u}$ cascada, $\boldsymbol{s} \boldsymbol{u}$ agua. "If they want to relax, they come to see the river. Tourists visit the river, its waterfall, its water". (Record)

- Que todo hay allí como aquí. Que igual tiene sus plantas y sus animales, sus hombres y sus mujeres. "Everything that is there is here. There are also their plants and their animals, their men and their women". [16]

Possessive pronouns are an integral part of speech in the languages of the OtoManguean group. Since these languages do not use articles, possessive pronouns indicate what belongs and to whom, i.e. they carry an additional clarification:

Table 3. Comparative analysis of phrases.

\begin{tabular}{|l|l|l|l|l|}
\hline Language & \multicolumn{1}{|c|}{$\begin{array}{l}\text { Indian } \\
\text { phrase }\end{array}$} & $\begin{array}{l}\text { Word-for-word } \\
\text { translation into } \\
\text { Spanish }\end{array}$ & $\begin{array}{l}\text { Loose translation } \\
\text { into Spanish }\end{array}$ & \multicolumn{1}{|c|}{$\begin{array}{c}\text { English } \\
\text { translation }\end{array}$} \\
\hline Amuzgo & $\begin{array}{l}\text { ¿Nchuu tyion' } \\
\text { quisondye } \\
\text { tsjuen'ho', } \\
\text { Santia? }\end{array}$ & $\begin{array}{l}\text { cuánto pagaste } \\
\text { vaca tuya } \\
\text { Santiago }\end{array}$ & $\begin{array}{l}\text { iCuánto pagaste por } \\
\text { tu vaca, Santiago? }\end{array}$ & $\begin{array}{l}\text { How much did } \\
\text { you pay for your } \\
\text { cow, Santiago? }\end{array}$ \\
\hline Zapotec & $\begin{array}{l}\text { Cala dyin } \\
\text { quia'. }\end{array}$ & $\begin{array}{l}\text { no.es trabajo } \\
\text { posesión - mía }\end{array}$ & No es mi trabajo. & It's not my job. \\
\hline Mazatec & $\begin{array}{l}\text { Cafeje nahmi } \\
\text { riji. }\end{array}$ & Llegó papá $\boldsymbol{t u}$ & ¿LLegó tu papá? & $\begin{array}{l}\text { Is your father } \\
\text { here? }\end{array}$ \\
\hline
\end{tabular}

In the state of Oaxaca, adverbs with the suffix -mente are widely used. This form is preferred in almost $100 \%$ of cases, where residents of the capital would use a preposition+noun., preposition+ adverb/ adverb muy "very" or bien "good" (in the meaning muy):

- Dentro de este tipo de público, espero que los maestros encuentren particularmente útil la edición de estas narraciones. "I hope that teachers will find the publication of stories very useful for this audience". [17]

- Millones de años moluscos que pertenecieron de hacer 110 millones de años aproximadamente. "Ancient molluscs that are approximately 110 million years old". (Record) 
- No es facilmente de ganarse la vida aquí. "It's hard to make a living here". (Record)

The authors of the Indian grammar textbooks in the word-for-word translation use the form on -mente:

Table 4. Comparative analysis of phrases.

\begin{tabular}{|l|l|l|l|l|}
\hline Language & \multicolumn{1}{|c|}{$\begin{array}{l}\text { Indian } \\
\text { phrase }\end{array}$} & $\begin{array}{l}\text { Word-for-word } \\
\text { translation into } \\
\text { Spanish }\end{array}$ & $\begin{array}{l}\text { Loose translation } \\
\text { into Spanish }\end{array}$ & English translation \\
\hline Amuzgo & $\begin{array}{l}\text { Mayuu' } \\
\text { chjoncyaa' } \\
\text { xjöhö }\end{array}$ & $\begin{array}{l}\text { Verdaderamente } \\
\text { muy miedoso tía- } \\
\text { mía }\end{array}$ & $\begin{array}{l}\text { Mi tía tiene mucho } \\
\text { miedo. }\end{array}$ & $\begin{array}{l}\text { My aunt is very } \\
\text { afraid. }\end{array}$ \\
\hline Zapotec & $\begin{array}{l}\text { Relë'ëro } \\
\text { dyë'di. }\end{array}$ & $\begin{array}{l}\text { Nuevamente - ve } \\
\text {-nosotros bien. }\end{array}$ & $\begin{array}{l}\text { Vemos bien otra } \\
\text { vez. }\end{array}$ & We can see it again. \\
\hline
\end{tabular}

The local use of auxiliary verbs can be observed. Auxiliary verbs can replace each other or other semantic verbs are used instead of these verbs, but in the sense of auxiliary verbs:

- Pedimos al gobierno apoyo sino hasta ahora es nada... (no hay nada) "We've asked the government for help, but so far there is nothing". (Record)

- Yo trabajé primero con un grupo y ese grupo fue creciendo (estuvo) "Firstly, I worked with a group that gradually increased". (Record)

- Tan solo en Oaxaca conviven cinco familias lingüísticas cuando en toda Europa apenas lo hacen tres (son) "Only in Oaxaca five language families coexist, while in all of Europe there are only three". [9]

In Indian languages, there is such a phenomenon as the absence of a linking verbs, which can be seen from the word-for-word translation, and in a loose translation, the verbbundle appears:

Table 5. Comparative analysis of phrases.

\begin{tabular}{|l|l|l|l|l|}
\hline Language & \multicolumn{1}{|c|}{$\begin{array}{l}\text { Indian } \\
\text { phrase }\end{array}$} & $\begin{array}{c}\text { Word-for-word } \\
\text { translation into } \\
\text { Spanish }\end{array}$ & $\begin{array}{l}\text { Loose translation } \\
\text { into Spanish }\end{array}$ & English translation \\
\hline Mixtec & Nda'u de. & pobre él & Él es pobre. & He's poor. \\
\hline Amuzgo & $\begin{array}{l}\text { Ndyioo } \\
\text { yotsca. }\end{array}$ & Pálidos niños & $\begin{array}{l}\text { Los niños están } \\
\text { pálidos. }\end{array}$ & Children are pale. \\
\hline Mixe & $\begin{array}{l}\text { Ca' } \\
\text { yjanchity }\end{array}$ & no cierto & No es cierto. & That's not true. \\
\hline
\end{tabular}

The Oaxacans, in both colloquial and written speech, make extensive use of future time in the approximate sense:

- Cuando Ernesto Zedillo fue a Ayautla a inaugurar un tramo de la carretera, hará unos dos años, le cayó un chapuzón que dijo ser el remojo que fue la bienvenida del lugar (la naturaleza). "When Ernesto Zedillo went to Ayautla to open a section of the highway, about two years ago, he got caught in heavy rain, saying it was a greeting from the place". [8]

- Hará como un año que vino un inspector del gobierno. "About a year ago the inspector came". (Record)

It is possible that Oaxacans have assimilated the form so easily in Spanish due to the fact that in the Indian languages of the Oto-Manguean group there is a similar grammatical form. For example, in the Mixtec language, changing the initial letter of the verb + " $k$ " at the beginning of the verb has a subjunctive meaning: jini - "sabe" (knows) $\rightarrow$ kuni "sabrá" (probably knows). And in the Chinantec, the prefix -ni conveys the subjunctive mood: ee- - "enseña" $\rightarrow$ ni' ee - "enseñará". 
Table 6. Comparative analysis of phrases.

\begin{tabular}{|l|l|l|l|l|}
\hline \multicolumn{1}{|c|}{ Language } & \multicolumn{1}{|c|}{$\begin{array}{c}\text { Indian } \\
\text { phrase }\end{array}$} & $\begin{array}{c}\text { Word-for-word } \\
\text { translation into } \\
\text { Spanish }\end{array}$ & $\begin{array}{c}\text { Loose translation } \\
\text { into Spanish }\end{array}$ & \multicolumn{1}{|c|}{$\begin{array}{c}\text { English } \\
\text { translation }\end{array}$} \\
\hline Mixtec & $\begin{array}{l}\text { Kaa de kucu } \\
\text { isu }\end{array}$ & $\begin{array}{l}\text { comerá él carne } \\
\text { venado }\end{array}$ & $\begin{array}{l}\text { Él comerá carne de } \\
\text { venado. }\end{array}$ & $\begin{array}{l}\text { He'll probably } \\
\text { eat deer meat. }\end{array}$ \\
\hline Mixtec & $\begin{array}{l}\text { Ki.in de } \\
\text { Ndinuu. }\end{array}$ & irá.allá él Tlaxiaco. & Él irá a Tlaxiaco. & $\begin{array}{l}\text { He'll probably go } \\
\text { to Tlaxiaco. }\end{array}$ \\
\hline Chinantec & ningī & caminaré & Caminaré & I think I'll go. \\
\hline
\end{tabular}

There is a common usage of the particle $\boldsymbol{n i}$ in the state of Oaxaca in the meaning: tampoco, no, ni siquiera, aun, hasta (also no, not, not even, even).

- Este año casi ni llovio. "It didn't even rain this year." (Record)

- «Somos pobres, no tenemos ni maíz», dijo el cazador. "We are poor; we don't even have enough for corn." [17]

- Estas fuentes impresas, salvo en contadas excepciones, no existen para la cultura mixe ni para la mayoría de las culturas indígenas; la recopilación tiene que partir directamente de la oralidad y esto involucra trabajar directamente con los miembros de las comunidades. "These published sources, with some exceptions, do not exist for the Mixe culture, nor for most indigenous cultures; the collection of information must begin directly with oral speech and this involves working directly with the inhabitants of the region". [17]

It is possible that the a wide use the particle $\boldsymbol{n i}$ in the state is due to the fact that in the Indian languages of the Oto-Manguean group, for example, in Mazatec, there is the word ni. Indian ni has two meanings: 1 . it means the past tense; 2 . the meaning of "nada más" only, just and "luego" - then.

Table 7. Comparative analysis of phrases.

\begin{tabular}{|l|l|l|l|l|}
\hline Language & \multicolumn{1}{|c|}{$\begin{array}{c}\text { Indian } \\
\text { phrase }\end{array}$} & $\begin{array}{l}\text { Word-for-word } \\
\text { translation into } \\
\text { Spanish }\end{array}$ & $\begin{array}{l}\text { Loose translation } \\
\text { into Spanish }\end{array}$ & \multicolumn{1}{|c|}{$\begin{array}{c}\text { English } \\
\text { translation }\end{array}$} \\
\hline Mixtec & $\begin{array}{l}\text { Ïyó } \overline{11}-\boldsymbol{n i} \\
\text { ve'e. }\end{array}$ & $\begin{array}{l}\text { Nada más hay una } \\
\text { casa }\end{array}$ & Hay solo una casa. & $\begin{array}{l}\text { There's only } \\
\text { one house. }\end{array}$ \\
\hline Mixtec & $\begin{array}{l}\text { Ya'á- } \\
\text { kúu jee } \\
\text { kun'í na. }\end{array}$ & $\begin{array}{l}\text { Quiero esto nada } \\
\text { más. }\end{array}$ & Quiero solo esto. & $\begin{array}{l}\text { That's all I } \\
\text { want. }\end{array}$ \\
\hline
\end{tabular}

In Oaxacan's speech often use no más by analogy with the Indian languages in the meaning "only", "just":

- ...asi no más inventando... = (solo) nada más “...So just inventing...” (Record)

- ... pagan no más a $2.50 \ldots$.. “...they pay only $2.50 . . . ”$ (Record)

- Nada más eso es lo que tenía que contar. "That's all I wanted to tell you (This is the only thing I wanted to tell you.)". [17]

The use of interjections "Aa", "Aha/ aja" instead of the Spanish "sí" - "yes" is noted: «Aja, voy a ir a tu casa». $\rightarrow$ "Yes, I will visit you".

Speaking of interjections, Oaxacans, mainly of the western and central part of the state, use "Aa" as a statement (instead of "yes"/ "yeah") in Mixe language and its variant "Aha" among the Mixtecs, Mazatecs and Zapotecs. In Spanish, this interjection is rendered as "Ah" in the letter. Here is a passage with a translation from mixe's story:

- "Ah" dijo.

- "Pues yo lo sorprendí haciéndoles eso"- dijo.

- "No hay problema, ahorita que los cure a todos" - dijo.

- "Ahorita que los cure"- dijo. 
- "Ah"- dijo la mujer.// "Yeah," - he said.

"Well, I caught him doing it,"- she said.

"No problem, let him heal everyone right now," - he said. "Let him treat them right now," - he said.

"Yeah," - said the woman. [17]

\section{Discussion}

In summary, some general observations can be made. The interaction between autochthonous languages of the state and the Spanish language of the colonizers had a special had a special influence on the speech of the inhabitants of the region. Spanish in the Mexican state of Oaxaca has a local specificity. Indian languages have influenced and continue to influence the grammatical forms in the region.

The results of the study make it possible to gain a deeper insight into the functioning of the various dialects of modern Spanish; to analyze the specifics of the speech behavior of Spanish speakers in different territories; to determine the trends of its development; to show the formation of its own territorial norms in the state of Oaxaca.

This issue is of interest for further consideration and development. As it became clear from the material presented that in each of the countries of the Spanish-speaking world, along with the classical version of the Castilian language, there is its own language with dialect inclusions and the influence of the native substrate. The resulting data that is important for construction of universals provides an insight into the processes that have taken place in the history of a language. [3]

\section{Conclusion}

As a result of the data obtained, there are prospects for further study of the Oaxaca dialect.

It would be interesting to study in more detail the influence of Indian languages on Spanish. Considering the fact that Indian languages are tonal this also affects grammatical forms. For example, in Indian languages, elongation of tone indicates the plural, in some cases, elongation of vowel replaces the final $-\mathrm{s}$ which indicates plural. Also, the projection and embodiment of the Indian world view in Spanish. For example, the animateness of absolutely all objects, even those that are inanimate in the European sense, is reflected in grammatical forms. The pronoun "le" refers to both animate and inanimate objects. The Asian tradition of using a noun denoting a person, with additional words: -san (jap.), -ge (Chin.), -nim (Kor.). For example, in Amuzgo language, there is a suffix similar to Spanish -ito, denoting polite treatment. Within the state, the use of the suffix -ito with proper names is noted.

\section{References}

1. E.V. Karpina, The modern language situation in Mexico as a reflection of the differentiation of the Spanish language, https://cyberleninka.ru/article/n/sovremennaya-yazykovaya-situatsiya-v-meksike-kakotrazhenie-differentsiatsii

2. E.V. Karpina, On the question of the variability of the Spanish language in the Mexican Yucatan

Peninsula, https://ling.tspu.edu.ru/files/ling/PDF/articles/karpina_e._v._19_28_1_11_2016.pdf

3. N.F. Mikheeva, S.D. Clemente-Smirnova, Questions of Ibero-Romance. Collection of articles (M., MAKS Press, 2021) 
4. G.V. Stepanov, On the problem of linguistic variation: the Spanish language of Spain and America (Moscow, Nauka, 1979)

5. O.S. Chesnokova, Reflection of the linguistic picture of the world in the development of the lexical system of the Mexican national variant of the Spanish language: dis. ... Dr. Filol. Sciences (Ros. University of Friendship of Peoples. M., 2006)

6. Alcibíades López López, Relatos mixtecos de la región de Santa María Yucuhiti. Tlaxiaco. Oaxaca. Versión en español y mixteco Oaxaca (México, 2017)

7. Bajó en México el ritmo de crecimiento poblacional: Inegi, https://www.jornada.com.mx/notas/2021/01/26/economia/bajo-en-mexico-el-ritmo-decrecimiento-poblacional-inegi/

8. Carole Vanden Hoek de Jamieson, Gramática mazateco de San Pedro Amuzgos (Oax Publicado por el Instituto Linguístico de Verano, A.C. México: 1988)

9. Ejemplos de las variantes del idioma mixteco, https://visionlinguistica.wordpress.com/2017/10/25/ejemplos-de-las-variantes-odialectos-del-idioma-mixteco/

10. Estadísticas del estado Oaxaca, http://www.digepo.oaxaca.gob.mx/recursos/publicaciones/hoja_poblacion_indigena.pd $\mathrm{f}$

11. Grupos étnicos de Oaxaca, https://www.linguateca.pt/GikiCLEF/GIRA/pool/GikiCLEF2009DocumentPool/es/g/r/ $\mathrm{u} / \mathrm{Gru}$

12. U.P. Henríquez, Revista de Filologia Española Madrid 8, 357 - 390 (1921)

13. J.M. Lope Blanch, Las zonas dialectales de México. Proyecto de delimitación (México, NRFH 19, 1970)

14. M.J. Buck, Gramática amuzga de San Pedro Amuzgos (Oax Publicado por el Instituto Linguístico de Verano, A.C. México, 2000)

15. Navarra Reyes Clara, Romero Luna Monzerrat, Ixcatecos (México, CDI, 2007) https://issuu.com/staffcom/docs/ixcatecos

16. Reyes Gómez Juan Carlos, Muerte-vida-fin principio ayuuk. Tuk it ets ja tuk it. Este mundo, el otro mundo, https://www.jornada.com.mx/2006/01/16/oja105- juan.html

17. R. Romero Méndez, Historias Mixes de Ayutla. Así contaron los abuelos. Universidad Nacional Autónoma de México (Instituto de Investigaciones Filológicas, México, 2013) 